Article

\title{
Enhanced Production of Gypenoside LXXV Using a Novel Ginsenoside-Transforming $\beta$-Glucosidase from Ginseng-Cultivating Soil Bacteria and Its Anti-Cancer Property
}

\author{
Chang-Hao Cui ${ }^{1}$, Da Jung Kim ${ }^{2}$, Suk-Chae Jung ${ }^{1}$, Sun-Chang Kim ${ }^{1,2,3, *}$ and Wan-Taek Im ${ }^{4, *}$ \\ 1 Intelligent Synthetic Biology Center, 291 Daehak-ro, Yuseong-gu, Daejeon 305-701, Korea; \\ seldoms@163.com (C.-H.C.); scjung@kaist.ac.kr (S.-C.J.) \\ 2 Department of Biological Sciences, Korea Advanced Institute of Science and Technology, 291 Daehak-ro, \\ Yuseong-gu, Daejeon 305-701, Korea; kimdj1404@kaist.ac.kr \\ 3 KAIST Institute for Biocentury, Korea Advanced Institute of Science and Technology, 291 Daehak-ro, \\ Yuseong-gu, Daejeon 305-701, Korea \\ 4 Department of Biological Sciences, Hankyong National University, 327 Chungang-no Anseong-si, \\ Kyonggi-do 456-749, Korea \\ * $\quad$ Correspondence: sunkim@kaist.ac.kr (S.-C.K.); wandra@hknu.ac.kr (W.-T.I.); Tel.: +82-42-350-4450 (S.-C.K.); \\ +82-31-670-5335 (W.-T.I.); Fax: +82-42-350-2619 (S.-C.K.); +82-31-670-5339 (W.-T.I.)
}

Academic Editor: Qing-Wen Zhang

Received: 14 March 2017; Accepted: 12 May 2017; Published: 19 May 2017

\begin{abstract}
Minor ginsenosides, such as compound $\mathrm{K}, \operatorname{Rg}_{3}(S)$, which can be produced by deglycosylation of ginsenosides $\mathrm{Rb}_{1}$, showed strong anti-cancer effects. However, the anticancer effects of gypenoside $\mathrm{LXXV}$, which is one of the deglycosylated shapes of ginsenoside $\mathrm{Rb}_{1}$, is still unknown due to the rarity of its content in plants. Here, we cloned and characterized a novel ginsenoside-transforming $\beta$-glucosidase (BglG167b) derived from Microbacterium sp. Gsoil 167 which can efficiently hydrolyze gypenoside XVII into gypenoside LXXV, and applied it to the production of gypenoside LXXV at the gram-scale with high specificity. In addition, the anti-cancer activity of gypenoside LXXV was investigated against three cancer cell lines (HeLa, B16, and MDA-MB231) in vitro. Gypenoside LXXV significantly reduced cell viability, displaying an enhanced anti-cancer effect compared to gypenoside XVII and $\mathrm{Rb}_{1}$. Taken together, this enzymatic method would be useful in the preparation of gypenoside LXXV for the functional food and pharmaceutical industries.
\end{abstract}

Keywords: gypenoside LXXV; gypenoside XVII; ginsenoside; deglycosylation; biotransformation; Microbacterium sp. Gsoil 167

\section{Introduction}

Ginseng (Panax ginseng C.A. Meyer) has been widely used to treat various diseases for thousands of years in Asian countries and, nowadays, is used as a medicinal herb or functional food all over the world [1,2]. Ginsenosides are considered as the main active ingredients responsible for pharmacological activities of the ginseng root, such as anti-cancer, anti-obesity, anti-inflammatory, antioxidant, and hepatoprotective activities [3-7]. The six major ginsenosides $\left(R b_{1}, R b_{2}, R c, R d\right.$, $\mathrm{Re}$, and $\mathrm{Rg}_{1}$ ) constitute more than $80 \%$ of the total ginsenosides in ginseng root, and various minor ginsenosides $\left(\operatorname{Rg}_{3}(S), \mathrm{Rh}_{2}(S), \mathrm{F}_{2}\right.$, compound $\mathrm{K}(\mathrm{C}-\mathrm{K}), \mathrm{Rg}_{2}(S), \mathrm{Rh}_{1}(S), \mathrm{F}_{1}$, protopanaxadiol (PPD) and protopanaxatriol (PPT), and gypenoside XVII (GypXVII)) that are deglycosylated from the major ginsenosides exist in smaller amounts in ginseng [8-11]. Major ginsenoside $\mathrm{Rb}_{1}$ is relatively abundant in ginseng, and it can be deglycosylated into rare minor ginsenosides $\left(\mathrm{F}_{2}, \operatorname{Rg}_{3}(S), \mathrm{Rh}_{2}(S), \mathrm{CK}, \mathrm{PPD}\right)$ which have enhanced anti-cancer activities [12,13]. 
GypXVII and gypenoside LXXV (GypLXXV), which have primarily been found in Gynostemma pentaphyllum are also the deglycosylated products of major ginsenoside $\mathrm{Rb}_{1}$ [14]. However, the pharmacological effects of GypXVII and GypLXXV is still unknown, because of their rare contents in G. pentaphyllum or P. ginseng C.A. Meyer. Although various purification methods were developed to improve the yield of saponins from the raw plants, neither GypXVII nor GypLXXV have been purified enough from raw plants for pharmacological study [15].

In this study, we isolated a novel ginsenoside-transforming $\beta$-glucosidase (BglG167b) from a ginseng-cultivating soil bacteria. BglG167b was cloned and overexpressed in Escherichia coli and the enzymatic properties and substrate specificities were investigated. This enzyme could hydrolyze various ginsenosides $\left(\mathrm{Rb}_{1}, \mathrm{Rb}_{2}, \mathrm{Rc}, \mathrm{Rd}, \mathrm{Rg}_{3}(S), \mathrm{F}_{2}, \mathrm{Re}, \mathrm{Rg}_{1}, \mathrm{GypXVII}\right)$ through various cleavage pathways, and has been applied for the production of GypLXXV from GypXVII at the gram-scale. Eventually, the pure GypLXXV was used for the study of anti-cancer effects against three kinds of cancer cells in vitro.

\section{Results and Discussion}

\subsection{Isolation and Characterization of Strain Microbacterium sp. Gsoil 167}

Strain Gsoil 167 which has been isolated from ginseng cultivating soil was confirmed to hydrolyze $\mathrm{Rg}_{1}$, Re and $\mathrm{Rb}_{1}$ into PPT and PPD, respectively (Data not shown), and was selected for the screening of ginsenoside-transforming enzymes. Phylogenetic analysis based on 16S rRNA gene sequences indicated that the isolate belongs to the genus Microbacterium in the phylum Actinobacteria, and is most closely related to Microbacterium luteolum IFO $15074^{\mathrm{T}}$ (99.9\% similarity).

\subsection{Fosmid Library Construction and Cloning of BglG167b}

Genomic DNA from Microbacterium sp. Gsoil 167 was isolated by phenol-chloroform extraction and used to generate a fosmid library. $\beta$-D-glucosidase activity was detected from a fosmid vector containing an inserted contig $(9.4 \mathrm{~kb})$. Twenty-three (23) putative ORFs of longer than 300 codons have been found using an ORF FINDER [16] analysis. Among them, one was homologous to glycoside hydrolase genes in glycoside hydrolase family 3 (GH3). This ORF, termed BglG167b, consisting of 2412 bp encoding 803 amino acids, was amplified via polymerase chain reaction (PCR) and then inserted into the pGEX $4 \mathrm{~T}-1$ vector.

\subsection{Phylogenetic Analysis of BglG167b Sequences}

The $\beta$-glucosidase (BglG167b) has a predicted molecular mass of $90.3 \mathrm{kDa}$ and a theoretical $p I$ value of 4.56 [17]. Analysis of the amino acid sequences of BglG167b indicated that it was $79 \%$ identical to the glycoside hydrolase of Microbacterium paraoxydans (GenBank number WP_018187396), which belongs to GH3. The enzyme from M. paraoxydans has not yet been characterized. The nearest characterized glycoside hydrolase in GH3 in the CAZy database was $\beta$-D-glucosidase from Agrobacterium tumefaciens, which was $40 \%$ identical to BglG167b based on amino acid sequences [18]. The phylogenetic analysis resulting consensus tree is presented in Figure S1. BglG167b clustered within subfamily 5 and formed a separate, well-supported clade (bootstrap of 100) with cellobiase of Cellulomonas biazotea, uncultured bacterium $\beta$-glucosidase and uncultured rumen bacterium $\beta$-glucosidase [19-21].

Various ginsenoside-hydrolyzing $\beta$-glucosidases in GH3 have been previously characterized, including two $\beta$-glucosidases (Bgp1 and Bgp3) from Microbacterium esteraromaticum, a $\beta$-glucosidase (rApy-H11) from Bifidobacterium longum H-1, a $\beta$-glucosidase (BGL1) from Aspergillus niger, a $\beta$-glucosidase (BglAm) from Actinosynnema mirum, a $\beta$-glucosidase (BgpA) from Terrabacter ginsenosidimutans, and a $\beta$-glucosidase (BglSk) from Sanguibacter keddieii [22-29]. The relationship between BglG167b and these ginsenoside-hydrolyzing $\beta$-glucosidases is presented in Figure S1. 


\subsection{Purification of Recombinant BglG167b}

The GST-fused BglG167b protein was purified using GST-Bind agarose resin. The recombinant enzyme was purified by GST-Bind agarose resin, and then the purified protein was determined using SDS-PAGE analysis (Figure 1). The molecular mass of the GST-BglG167b calculated via an amino acid sequence was $116 \mathrm{kDa}$, which is similar to the mass detected by SDS-PAGE. In addition, the recombinant GST-BglG167b contains $36.5 \pm 1.4 \%$ of total soluble proteins in the cell lysate.

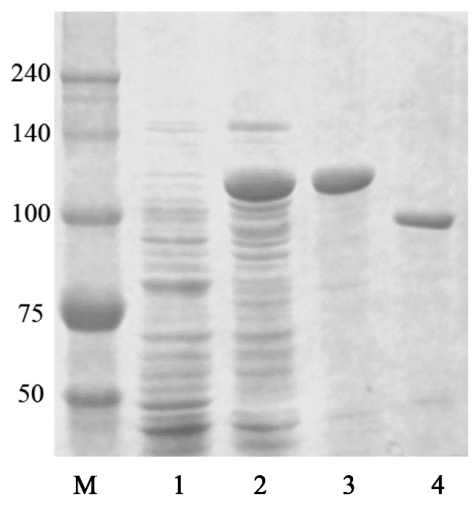

Figure 1. SDS-PAGE analysis of recombinant BglG167b. Lane M, molecular weight standard; lane 1, crude extract of BL21 (DE3) carrying pGEX-BglG167b without induction; lane 2, soluble fraction in crude extract of BL21 (DE3) carrying pGEX-BglG167b after induction; lane 3, GST-BglG167b enzyme fraction after purification with the GST-bind agarose resin; lane 4, purified recombinant BglG167b after cleavage by thrombin2.5. Characterization of recombinant BglG167b.

The optimum temperature and $\mathrm{pH}$ were characterized using purified GST-BglG167b. The optimal temperature activity was $45^{\circ} \mathrm{C}$; at $30^{\circ} \mathrm{C}$ and $37^{\circ} \mathrm{C}$, the enzyme has $75.0 \%$ and $89.8 \%$ of relative activity, while thermo-stability was decreased significantly from $45^{\circ} \mathrm{C}$, and not detected after incubation at $45^{\circ} \mathrm{C}$ for $2 \mathrm{~h}$ (Figure 2A). The enzyme was stable at temperatures lower than $30^{\circ} \mathrm{C}$, and about $86.4 \%$ of the activity was lost after incubation at $37^{\circ} \mathrm{C}$ for $2 \mathrm{~h}$ (Figure 2A). The optimal temperature for the BglG167b activity was similar to the $\beta$-glucosidase isolated from $T$. ginsenosidimutans $\left(45^{\circ} \mathrm{C}\right)$ [22] . BglG167b had optimal $\mathrm{pH}$ activity at $\mathrm{pH} 7.0$ in a sodium phosphate buffer; BglG167b is stable from pH 6.0 to 9.0; at pH 5.0 to 10.0 , the enzyme stability decreased swiftly, while at pH 5.0 and 10.0 the enzyme activity decreased to $1.2 \%$ and $40.0 \%$ (Figure $2 \mathrm{~B}$ ). The enzyme is probably mesophilic and stable at a neutral $\mathrm{pH}$ range. These optimal conditions are consistent with the soil environment from which Microbacterium sp. Gsoil 167 was isolated. In addition, the near-neutral optimal pH and mild optimal temperature of BglG167b are similar to those of other ginsenoside-hydrolyzing GH3 from bacteria $[22,23,27,29,30]$. Although the optimum temperature of $\mathrm{BglG167b}$ for $p$ NPGlc is $45^{\circ} \mathrm{C}$, the ginsenoside-conversion reaction occurred at $37^{\circ} \mathrm{C}$ for the extension of stable transformation activity.
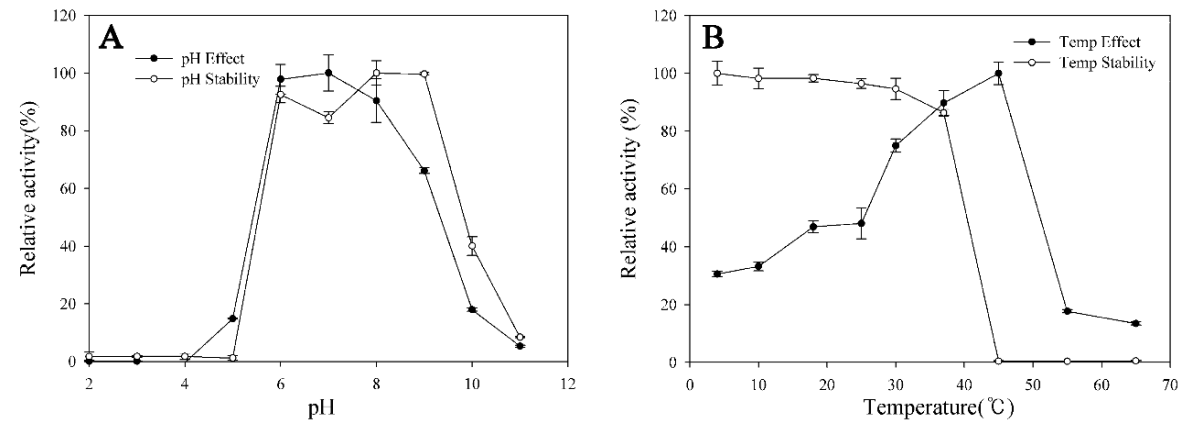

Figure 2. Effects of $\mathrm{pH}(\mathbf{A})$ and temperature $(\mathbf{B})$ on the stability and activity of recombinant BglG167b. 
The effects of metal ions, EDTA, DTT, and SDS on BglG167b activity were also studied (Table S1). BglG167b activity was affected by $10 \mathrm{mM}$ of $\beta$-mercaptoethanol, which is a well-known thiol group inhibitor. This suggested that sulfhydryl groups may be involved in the catalytic center of the enzyme. The enzyme was not affected by $\mathrm{Na}^{+}, \mathrm{K}^{+}, \mathrm{Mn}^{2+}$, and $\mathrm{Mg}^{2+}$. The chelating agent EDTA inhibits BglG167b activity, which indicated that divalent cations may be required for enzymatic activity. The enzyme activity appeared to be strongly inhibited in the presence of $\mathrm{Ca}^{2+}, \mathrm{SDS}, \mathrm{Zn}^{2+}, \mathrm{Co}^{2+}$, and $\mathrm{Cu}^{2+}$. However, no dramatic positive effect on the activity of the BglG167b was found for the tested ions.

The substrate specificity of BglG167b was tested using $2.0 \mathrm{mM}$ of $p$-nitrophenyl $(p \mathrm{NP})$ and $o$-nitrophenyl (oNP)-glycosides with $\alpha$ and $\beta$ configurations. The results showed that BglG167b was active against glucose moiety of $p \mathrm{NP}-\beta-\mathrm{D}-$ glucopyranoside and $o \mathrm{NP}-\beta$-D-glucopyranoside. It showed maximum activity towards $p$ NP- $\beta$-D-glucopyranoside, $8.1 \%$ relative activity towards $p$ NP- $\alpha$-D-glucopyranoside and $22.9 \%$ relative activity towards $o \mathrm{NP}-\beta$-D-glucopyranoside (Table S2).

\subsection{Transformation Characteristics of BglG167b}

For the verification of the bioconversion pathways of the nine ginsenosides $\left(R b_{1}, R b_{2}, R c, R d\right.$, GypXVII, $\operatorname{Rg}_{3}(S), F_{2}$, Re and $\operatorname{Rg}_{1}$ ) by BglG167b, the TLC analyses were performed at regular intervals. GST-BglG167b could clearly transform nine ginsenosides, as shown by the $R_{\mathrm{f}}$ values of the TLC analysis (Figure 3).
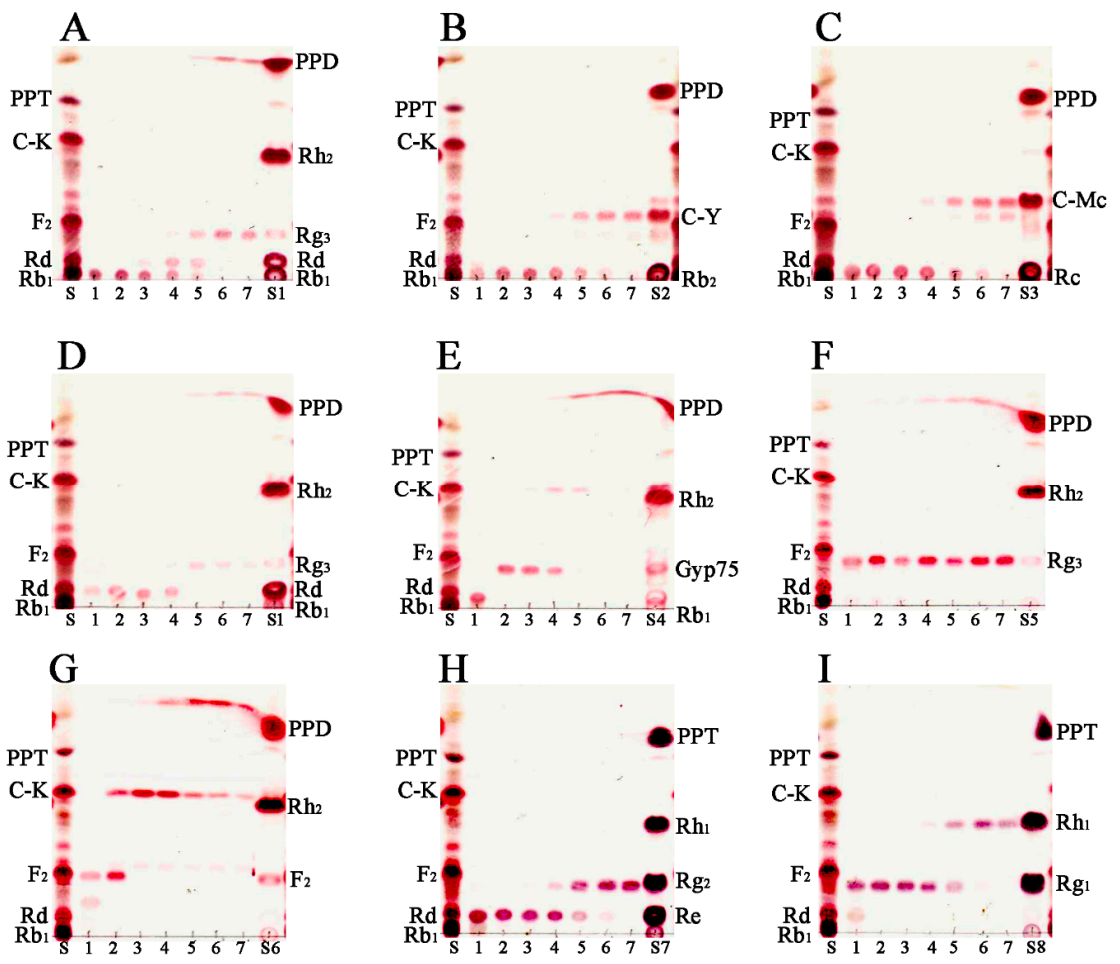

Figure 3. TLC analyses of time-course of ginsenoside bioconversion by BglG167b at an enzyme concentration of $1.0 \mathrm{mg} / \mathrm{mL}$. (A) the transformation of $\mathrm{Rb}_{1} ;(\mathbf{B})$ the transformation of $\mathrm{Rb}_{2} ;(\mathbf{C})$ the transformation of Rc; (D) the transformation of Rd; (E) the transformation of gypenoside XVII; (F) the transformation of $\operatorname{Rg}_{3}(S) ;(G)$ the transformation of $\mathrm{F}_{2} ;(\mathbf{H})$ the transformation of $\mathrm{Re}$; and $(\mathrm{I})$ the transformation of ginsenoside $\mathrm{Rg}_{1}$. Developing solvent: $\mathrm{CHCl}_{3}-\mathrm{CH}_{3} \mathrm{OH}-\mathrm{H}_{2} \mathrm{O}$ (70:30:10, $v / v$, lower phase). Lane $S$, standards ( $\left.\mathrm{Rb}_{1}, \mathrm{Rd}, \mathrm{F}_{2}, \mathrm{C}-\mathrm{K}, \mathrm{PPT}, \mathrm{PPD}\right)$; Lane $S 1$, standards $\left(\mathrm{Rb}_{1}, \operatorname{Rd}_{1} \operatorname{Rg}_{3}(S), \operatorname{Rh}_{2}(S)\right.$, PPD); Lane S2, standards ( $\left.\mathrm{Rb}_{2}, \mathrm{C}-\mathrm{Y}, \mathrm{PPD}\right)$; Lane S3, standards (Rc, C-Mc, PPD); Lane S4, standards $\left(\mathrm{Rb}_{1}\right.$, GypXVII, GypLXXV, $\left.\mathrm{Rh}_{2}(S), \mathrm{PPD}\right)$; Lane S5, standards $\left(\operatorname{Rg}_{3}(S), \mathrm{Rh}_{2}(S), \mathrm{PPD}\right)$; Lane 66 , standards $\left(\mathrm{F}_{2}\right.$, $\left.\mathrm{Rh}_{2}(S), \mathrm{PPD}\right)$; Lane $\mathrm{S} 7$, ginsenoside standards ( $\left.\operatorname{Re}, \operatorname{Rg}_{2}(S), \mathrm{Rh}_{1}(S), \mathrm{PPT}\right)$; Lane $\mathrm{S} 8$, ginsenoside standards $\left(\mathrm{Rg}_{1}, \mathrm{Rh}_{1}(S), \mathrm{PPT}\right)$; Lane 1, control; Lane 2, 5 min; Lane 3, 30 min; Lane 4, 3 h; Lane 5, 10 h; Lane 6, 24 h; Lane $7,48 \mathrm{~h}$. 
In PPD-type ginsenosides, $\mathrm{Rb}_{1}$, $\mathrm{Rd}$, GypXVII, $\mathrm{Rb}_{2}$, and Rc have been converted by BglG167b. For $\mathrm{Rb}_{1}$ biotransformation, three types of metabolites ( $\left.\mathrm{Rd}, \mathrm{Rg}_{3}(S), \mathrm{PPD}\right)$ were detected as time passed (Figure 4A). BglG167b successively hydrolyzed the outer and inner glucose moieties at position C20, and the inner glucose at position C3. BglG167b transformed all GypXVII into GypLXXV in $5 \mathrm{~min}$, and continuously into C-K and PPD. The conversion speed of GypXVII was highest in all ginsenoside transformations of Bgl167b and it is the first enzyme in subfamily 5 which can hydrolyze GypXVII into GypLXXV. For $\mathrm{F}_{2}$ transformation, BglG167b produced C-K from $\mathrm{F}_{2}$, which means BglG167b prefers to hydrolyze glucose moiety at the $\mathrm{C} 3$ position than $\mathrm{C} 20$ when each position has one glucose moiety. According to the results of $p \mathrm{NP}$ and $o \mathrm{NP}$ substrates reactions, BglG167b could not hydrolyze arabinopyranoside and arabinofuranoside attached at the outer position of $\mathrm{C} 20$, but could hydrolyze two glucose moieties at C20. In PPT-type ginsenosides hydrolyzation, $\mathrm{Re}$ and $\mathrm{Rg}_{1}$ were transformed into $\operatorname{Rg}_{2}(S)$ and $\mathrm{Rh}_{1}(S)$, respectively, which means BglG167b cannot hydrolyze the attached sugars at $\mathrm{C} 6$, but glucose moieties at $\mathrm{C} 3$.
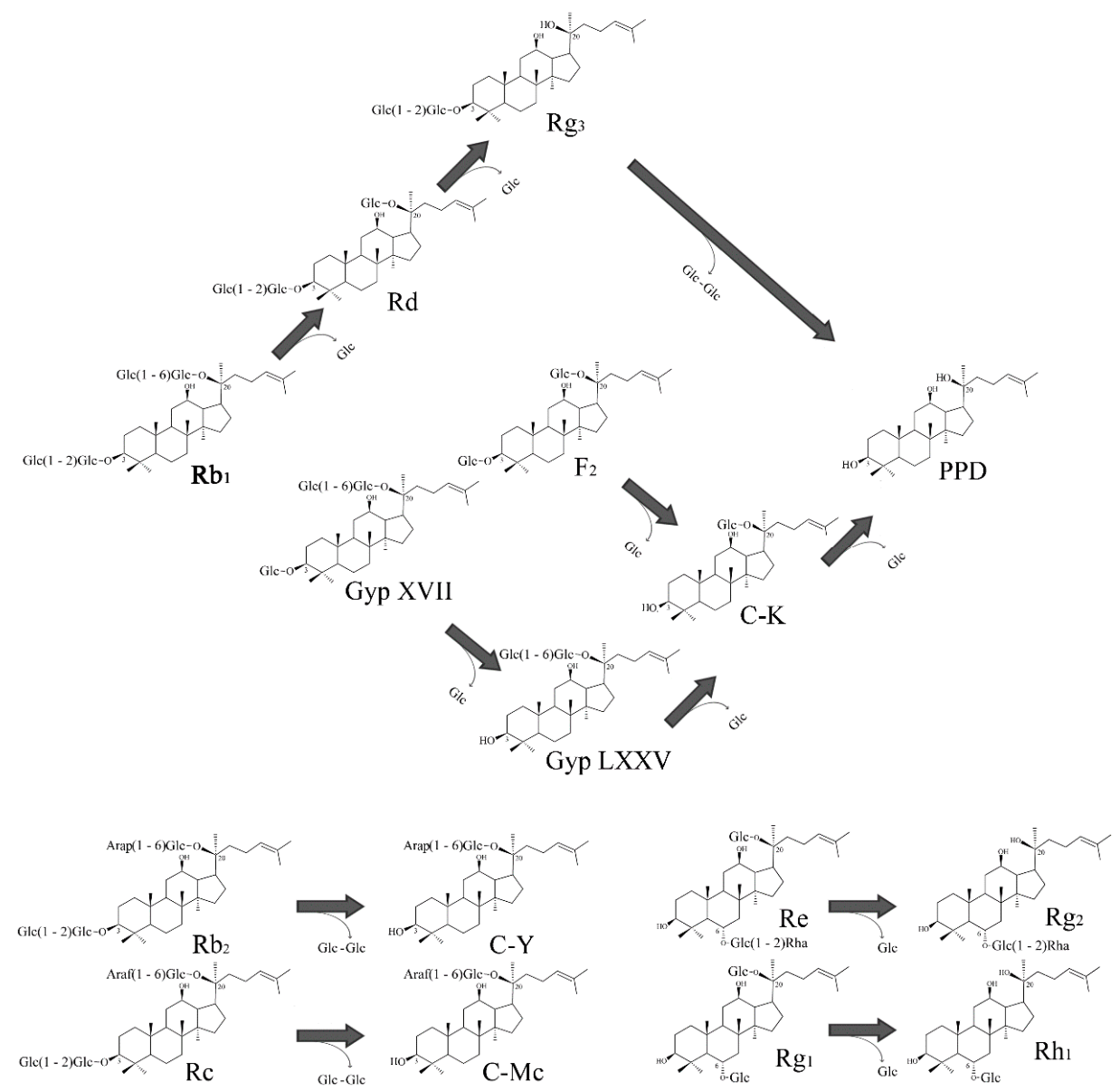

Figure 4. Transformation pathways of ginsenosides $\mathrm{Rb}_{1}, \mathrm{Rb}_{2}$, $\mathrm{Rc}$, $\mathrm{Rd}$, GypXVII, $\mathrm{Rg}_{3}(S), \mathrm{F}_{2}$, GypLXXV, $R e$, and $\operatorname{Rg}_{1}$ by recombinant BglG167b, respectively.

Summarizing the transformation pathways, the proposed biotransformation pathways by BglG167b for the ginsenosides are as follows: $\mathrm{Rb}_{1} \rightarrow \mathrm{Rd} \rightarrow \mathrm{Rg}_{3}(S) \rightarrow$ PPD; $\mathrm{Rd} \rightarrow \mathrm{Rg}_{3}(S) \rightarrow$ PPD; GypXVII $\rightarrow$ GypLXXV $\rightarrow$ C-K $\rightarrow$ PPD; $F_{2} \rightarrow$ C-K $\rightarrow$ PPD; $R_{2} \rightarrow$ C-Y; Rc $\rightarrow$ C-Mc; $R e \rightarrow \operatorname{Rg}_{2}(S) ; \operatorname{Rg}_{1}$ $\rightarrow \mathrm{Rh}_{1}(S)$ via the stepwise hydrolysis of glucose moieties at the $\mathrm{C} 20$, and $\mathrm{C} 3$ positions of aglycon (Figure 4).

The metabolic pathways of ginsenoside $\mathrm{Rb}_{1}, \mathrm{Rb}_{2}$, and Rc hydrolysis by BglG167b are similar to $\beta$-glucosidases from M. esteraromaticum and Flavobacterium johnsoniae, which is attributed to their 
high amino acid sequence similarity in subfamily 5, and they can provide $\mathrm{Rb}_{1} \rightarrow \operatorname{Rg}_{3}(S)$ conversions via hydrolysis of the outer and inner glucose at the $\mathrm{C} 20$ position of $\mathrm{Rb}_{1}$ (Figure $\mathrm{S} 1$ ) $[26,27,31]$. The transformation of GypXVII into GypLXXV has been found by $\beta$-glucosidases from $T$. ginsenosidimutans, A. mirum, and S. keddieii $[22,23,25]$. However, they simultaneously transform GypLXXV into C-K or PPD. On the other hand, the higher conversion ability of BglG167b makes it more efficient for the production of GypLXXV.

Previously, GypLXXV has been produced using microbial and enzymatic transformation, but the low concentration (less than $2.0 \mathrm{mg} / \mathrm{mL}$ ), long transformation time $(60 \mathrm{~h})$, and further deglycosylation limited its application to the production of GypLXXV [22,32]. GypXVII has been produced at a gram-scale from major ginsenoside $\mathrm{Rb}_{1}$ using $\mathrm{BgpA}$ [20], and used for the substrate for the production of GypLXXV. BglG167b could efficiently transform GypXVII into GypLXXV at a higher concentration $(5.0 \mathrm{mg} / \mathrm{mL})$ and in a shorter period $(9 \mathrm{~h})$.

\subsection{Scale-Up Production of GypLXXV and Purification}

The bacterial cells that harbor pGEX-BglG167b were incubated further for $18 \mathrm{~h}$ at $22{ }^{\circ} \mathrm{C}$ after induction and were harvested via centrifugation when the culture reached an OD of 40 at $600 \mathrm{~nm}$. One-hundred twenty-five grams (125 g) of wet cells were harvested and the pellets were resuspended in 10 volumes $(w / v)$ of $100 \mathrm{mM}$ sodium phosphate buffer ( $\mathrm{pH}$ 7.0). The cells were disrupted via ultrasonication and the supernatant was used as crude enzymes for the biotransformation of the ginsenosides.

Gram-scale GypXVII has been produced using recombinant BgpA from ginsenoside $\mathrm{Rb}_{1}$ (data not shown) [22]. The produced GypXVII (80.1\% chromatography purity) was used as the substrate for the gram-scale production of GypLXXV. The enzyme reaction occurred using the crude recombinant BglG167b with GypXVII as the substrate with a concentration of $5.0 \mathrm{mg} / \mathrm{mL}$. As shown in Figure 5, all GypXVII was converted to GypLXXV within $9 \mathrm{~h}$ (Figure 5B). Most of the produced GypLXXV was precipitated to form a solid, with a small quantity remaining dissolved in the supernatant.

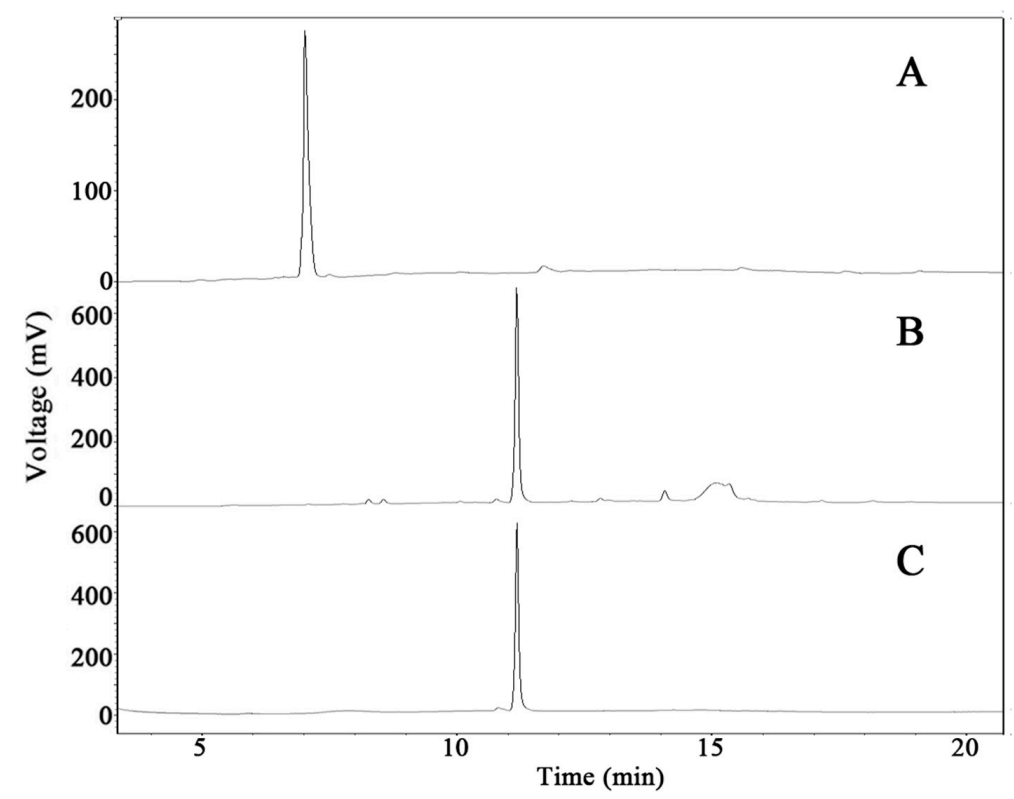

Figure 5. HPLC results of the production of GypLXXV from GypXVII by BglG167b; (A) substrate GypXVII; (B) the reaction mixture after nine-hour treatment with BglG167b; and (C) purified GypLXXV using Prep-HPLC.

In order to remove the free sugar, enzyme, and salt, the mixture was centrifuged at $5000 \mathrm{rpm}$ for $15 \mathrm{~min}$. After a purification step using column chromatography packed with HP20 resin, approximately 
3 BVs of the $95 \%$ ethanol eluent was evaporated in vacuo in order to create $5.7 \mathrm{~g}$ of GypLXXV. Its chromatographic purity was $83.1 \%$ as determined via high-performance liquid chromatography (HPLC) (Figure 5). For the anti-cancer activity study, further purification was performed using Prep-HPLC. An ODS column is used as the stationary phase and $75 \%$ acetonitrile was used as the mobile phase. GypLXXV was eluted from $150 \mathrm{~mL}$ to $280 \mathrm{~mL}$, and after recycling two times to remove impurity peaks, the compound with $97.8 \%$ purity was harvested. The recovery ratio through the biotransformation process using GypXVII to GypLXXV reached 69.6\% during the entire bioprocess engineering.

Relatively abundant major ginsenosides were normally used as substrates for the production of minor ginsenosides, and we have demonstrated several enhanced productions of rare minor ginsenoside $\operatorname{Rg}_{3}(S), F_{2}$, and $\operatorname{Rg}_{2}(S)$ using various ginsenoside-transforming recombinant enzymes [31,33,34] from major ginsenosides. These various enzymatic methods were reported thus far for the preparation of minor ginsenosides as a result of their higher conversion efficiency, fewer by-products, superior environmental protection, and better stereo-specificity than physiochemical methods and microbiological methods [35-37]. Efforts have also been made to produce GypLXXV by deglycosylation of relatively abundant ginsenoside $\mathrm{Rb}_{1}$ [22,32]. Due to its rarity, GypXVII has not been used as a substrate for the preparation of GypLXXV. In this study, recombinant BgpA which has been cloned from Terrabacter ginsenosidimutans Gsoil $3082^{\mathrm{T}}$ with high substrate tolerance $\left(\mathrm{Rb}_{1}, 50 \mathrm{mg} / \mathrm{mL}\right)$ and efficiency (5 h), was used for the gram-scale GypXVII preparation [22]. Previously, GypXVII has been used for the production of $\mathrm{F}_{2}$ and CK $[38,39]$. However, no gram-scale production of GypLXXV, which is important for industrial application, has been achieved before, and the gram-scale production of GypLXXV showed a strong possibility for more large scale applications of BglG167b.

\subsection{Cytotoxic Effect of GypLXXV on Cancer Cells}

In order to prove cytotoxic effects of GypLXXV on tumor cells, we compared the effect of $R b_{1}$, GypXVII, $\operatorname{Rg}_{3}(S)$ and GypLXXV on cell viability using three cancer cell lines (HeLa (cervical cancer cell line), B16 (melanoma cell line), and MDA-MB231 (human breast cancer cell line)). Doxorubicin, a well-known chemotherapy medication used to treat cancer, was used as a positive control. The cancer cells were treated with 1.0-100 $\mu \mathrm{M}$ of pure doxorubicin, $\mathrm{Rb}_{1}$, GypXVII, $\mathrm{Rg}_{3}(S)$, and GypLXXV for $48 \mathrm{~h}$ (Figure 6A-C). According to MTT assay results, treatment with $\operatorname{Rg}_{3}(S)$ and GypLXXV reduced proliferation in a dose-dependent manner (Figure $6 \mathrm{~A}-\mathrm{C}$ ). After $48 \mathrm{~h}$ of treatment, almost all cancer cells were inhibited by GypLXXV and $\operatorname{Rg}_{3}(S)$ at $50 \mu \mathrm{M}$. The $\mathrm{LC}_{50}$ of doxorubicin was lower than $\operatorname{Rg}_{3}(S)$ and GypLXXV on three cancer cells (Figure 6D). Though, as compared with LC50 doxorubicin and $\operatorname{Rg}_{3}(S)$ (Figure 6D), GypLXXV showed considerable anti-proliferate activities higher than $\mathrm{Rb}_{1}$ and GypXVII, and $63-78 \%$ of to ginsenoside $\operatorname{Rg}_{3}(S)$, which has shown strong anti-cancer effects in vitro and in vivo in accordance with many studies [40].

Anticancer effects of minor ginsenosides $\left(\mathrm{F}_{2}, \mathrm{Rg}_{3}(S), \mathrm{Rh}_{2}(S), \mathrm{CK}\right.$, and PPD) which were the deglycosylated form of ginsenoside $\mathrm{Rb}_{1}$, have been studied, and these minor ginsenosides showed strong activity against various cancer cell lines [41,42]. Among them, $\operatorname{Rg}_{3}(S)$ appeared on the market and has been applied to clinical therapy. GypLXXV has two glucose moieties attached at the C20 position of aglycon, whereas $\operatorname{Rg}_{3}(S)$ has two glucose moieties at $\mathrm{C} 3$ (Figure 4). The $\mathrm{LC}_{50}$ of GypLXXV showed similar anti-cancer effects with $\operatorname{Rg}_{3}(S)$ (Figure 6D), and higher than $\mathrm{Rb}_{1}$ and GypXVII, which have more attached glucose moieties (Figure 6A-C). It is the first report of the anti-cancer activity of GypLXXV, and the patent of the anti-cancer activity of GypLXXV against HeLa cells has been registered by this team [43]. These results demonstrate that deglycosylation contributes to improved anticancer activity, and the mechanism of increased anticancer effects requires further structure-related approaches. 

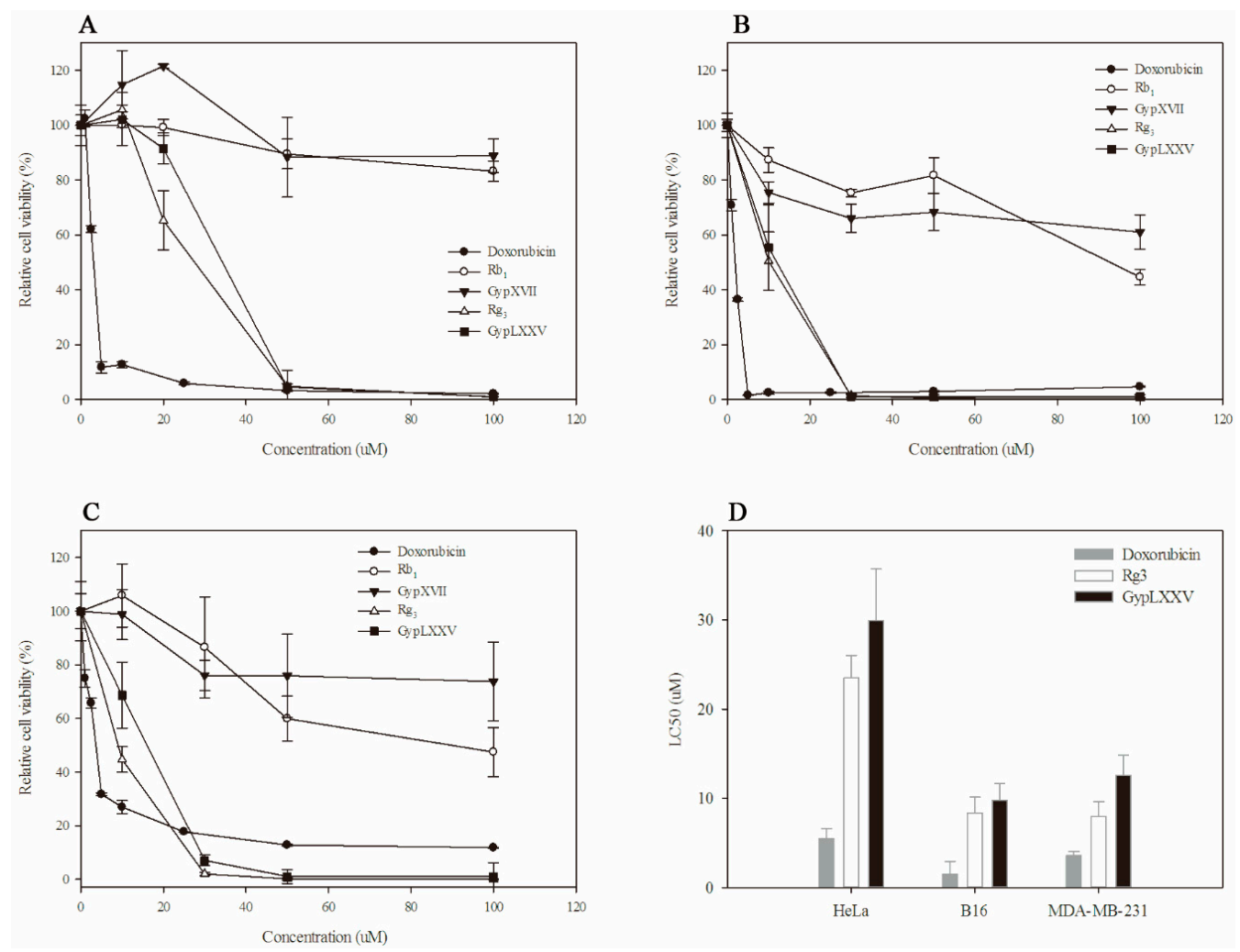

Figure 6. The anti-cancer effects of GypLXXV, $\operatorname{Rg}_{3}(S)$, GypXVII and $\mathrm{Rb}_{1}$ on cell viability on (A) HeLa cells; (B) B16 cells; (C) MDA-MB231; and (D) LC50 comparison of doxorubicin, $\operatorname{Rg}_{3}(S)$, and GypLXXV. Cancer cells were incubated with various concentrations of GypLXXV for $48 \mathrm{~h}$.

\section{Materials and Methods}

\subsection{Materials}

Ginsenoside standards that are over $98 \%$ purity, such as $\mathrm{Rb}_{1}, \mathrm{Rb}_{2}, \mathrm{Rc}, \mathrm{Rd}, \mathrm{Rg}_{3}(S), \mathrm{Rh}_{2}(S), \mathrm{F}_{2}$, compound $\mathrm{K}(\mathrm{C}-\mathrm{K})$, protopanaxadiol (PPD), $\mathrm{Rg}_{1}, \mathrm{Re}, \mathrm{Rg}_{2}(S), \mathrm{Rh}_{1}(S)$, and protopanaxatriol (PPT), were purchased from (Zelang Medical Technology Co., Ltd., Nanjing, China). HPLC grade acetonitrile was obtained from Merck (Darmstadt, Germany). GypXVII, GypLXXV, and ginsenosides compound O (C-O), compound $\mathrm{Y}(\mathrm{C}-\mathrm{Y})$, compound $\mathrm{Mc}_{1}\left(\mathrm{C}-\mathrm{Mc}_{1}\right)$, and compound $\mathrm{Mc}(\mathrm{C}-\mathrm{Mc})$, were prepared as described by Cui et al. [23]. 5-bromo-4-chloro-3-indolyl $\beta$-D-glucopyranoside (X-Glc) was purchased from Wako Co. Ltd. (Tokyo, Japan). The other chemicals used were a minimum of analytical reagent grade. Microbacterium sp. Gsoil 167, was isolated from a soil sample of a ginseng field, Pocheon Province, South Korea, and cultivated on R2A agar (Becton, Dickinson and Company, Franklin Lakes, NJ, USA) under aerobic conditions at $30^{\circ} \mathrm{C}$ and used for the gene cloning experiment. Escherichia coli BL21 (DE3), and pGEX 4T-1 plasmid (GE Healthcare, Chicago, IL, USA) were used as host and expression vector sources, respectively. The $E$. coli cells harboring the BglG167b-containing recombinant plasmid for protein expression was cultivated in a Luria-Bertani (LB) medium supplemented with ampicillin $(100 \mathrm{mg} / \mathrm{L})$.

\subsection{Fosmid Library Construction and Fosmid Sequencing}

A CopyControl ${ }^{\mathrm{TM}}$ Fosmid Production kit (Epicentre Technologies, Madison, WI, USA) was used to isolate the ginsenoside-hydrolyzing glycosidase genes from Microbacterium sp. Gsoil 167. A fosmid library was constructed following the manufacturer's protocol. Infected E. coli was transferred onto X-Glc (5-bromo-4-chloro-3-indolyl $\beta$-D-glucopyranoside) LB plates supplemented with $12.5 \mu \mathrm{g} / \mathrm{mL}$ chloramphenicol and then incubated at $37^{\circ} \mathrm{C}$ for $16 \mathrm{~h}$. The blue color colonies were selected as putative 
ginsenoside-hydrolyzing candidates. After confirmation of the ginsenoside-hydrolyzing activity by a TLC assay, one clone was selected for fosmid sequencing. Fosmid DNA was purified and sequenced by Macrogen Co. Ltd. (Seoul, Korea). The final sequences assembly procedure was conducted by the SeqMan program in the DNASTAR package (DNASTAR, Madison, WI, USA), which yielded a 9.4-kb contig.

\subsection{Phylogenetic Analysis of BglG167b}

A homology search was performed with BLAST program provided by NCBI database (blast.ncbi.nlm.nih.gov). Sequences of the characterized glycosyl hydrolases were obtained from the CAZY database [44], and multiple alignments were performed using the CLUSTAL_X program [45]. Gaps were modified in the BioEdit program [46], and evolutionary distances were calculated according to the Kimura two-parameter model [47]. A phylogenetic tree was constructed using the neighbor-joining method in the MEGA5 program, with bootstrap values based on 1000 replicates [48].

\subsection{Molecular Cloning, Expression, and Purification of Recombinant BglG167b}

The fosmid DNA sequence was analyzed using the ORF Finder program on the NCBI website (www.ncbi.nlm.nih.gov/gorf). Predicted ORFs were subjected to similarity searches using the BLAST program, which identified two putative open reading frames (ORFs) for $\beta$-glucosidases. One of them, BglG167b, which belonged to GH3 and consisted of 803 predicted amino acids, showed ginsenoside-transforming activities. To clone the gene encoding BglG167b, PCR amplification was conducted using primers containing BamHI and XhoI (BglG167b) restriction sites, respectively (bolded). The primer sequences were as follows: bglC167bF 5'-GGT TCC GCG TGG ATC CAA CGC CCG CCC GTC CGA TTC CAC C-3' and bglC167bR 5'-GAT GCG GCC GCT CGA GTC ATG CCT GCT CCC AGT CCA CCG A-3'. The amplified DNA fragment obtained from the PCR was purified and inserted into the pGEX 4T-1 using an EzCloning Kit (Enzynomics Co. Ltd., Daejeon, Korea). The recombinant pGEX-BglG167b was transformed into E. coli BL21 (DE3). The recombinant plasmid harboring E. coli BL21 (DE3) was grown in an LB-ampicillin medium at $37^{\circ} \mathrm{C}$ until the culture reached an $\mathrm{OD}_{600}$ of 0.6 , and then the recombinant protein expression was induced through $0.1 \mathrm{mM}$ isopropyl- $\beta$-D-thiogalactopyranoside (IPTG). The bacterial cells were incubated for a further $18 \mathrm{~h}$ at $18{ }^{\circ} \mathrm{C}$ and harvested via centrifugation at $13,000 \mathrm{rpm}$ for $15 \mathrm{~min}$ at $4{ }^{\circ} \mathrm{C}$. The cells were washed twice with a solution consisting of $50 \mathrm{mM}$ sodium phosphate, $5 \mathrm{mM}$ EDTA, and 1\% Triton X-100 ( $\mathrm{pH}$ 7.0); then, they were resuspended in $50 \mathrm{mM}$ sodium phosphate ( $\mathrm{pH}$ 7.0). The cells were lysed via ultrasonication (Vibra-cell, Sonics and Materials Inc., Newtown, CA, USA). The insoluble debris was removed via centrifugation at $13,000 \mathrm{rpm}$ for $15 \mathrm{~min}$ at $4{ }^{\circ} \mathrm{C}$ in order to obtain the crude cell extract. The GST-tagged BglG167b was purified using the GST bind agarose resin according to the manufacturer's protocol (Elpisbiotech Co. Ltd., Daejeon, Korea). The purity of the protein was assessed using 10\% SDS-PAGE and an EZ-Gel staining solution (Daeillab Co. Ltd., Seoul, Korea).

\subsection{Effect of $p H$, Temperature, Metal Ions, and Chemical Reagents on Enzyme Activity}

The specific activity of purified BglG167b was determined using $p N P-\beta$-D-glucopyranoside ( $p$ NPGlc) as a substrate in $\mathrm{pH} 7.0,50 \mathrm{mM}$ sodium phosphate buffer at $37^{\circ} \mathrm{C}$. Reactions were performed for $10 \mathrm{~min}$ by the addition of $\mathrm{Na}_{2} \mathrm{CO}_{3}$ (final concentration, $500 \mathrm{mM}$ ), and the release of $p$-nitrophenol was measured directly using a microplate reader at $405 \mathrm{~nm}$ (Bio-Rad Model 680; Bio-Rad., Hercules, CA, USA). One unit of activity was defined as the amount of protein required to generate $1 \mu \mathrm{mol}$ of $p$-nitrophenol per min. Protein concentrations were determined using the BCA protein assay protocol (Pierce, Rockford., IL, USA). All assays were performed in triplicate.

The effect of $\mathrm{pH}$ on enzymatic activity was determined as described [22]. The pH stability of recombinant BglG167b was determined by quantifying enzymatic activity after incubation in each buffer for $24 \mathrm{~h}$ at $4{ }^{\circ} \mathrm{C}$. The effect of temperature was tested by incubating the enzyme at various temperatures ranging from $4^{\circ} \mathrm{C}$ to $65^{\circ} \mathrm{C}$ at the optimum $\mathrm{pH}$ for $10 \mathrm{~min}$ containing $2.0 \mathrm{mM} \mathrm{pNPGlc}$. 
The thermostability of the enzyme was determined by incubating the enzyme in $50 \mathrm{mM}$ sodium phosphate buffer ( $\mathrm{pH}$ 7.0) for $2 \mathrm{~h}$ at different temperatures. After chilling the sample on ice for $10 \mathrm{~min}$, activity was determined using $p$ NPGlc.

The effects of metals and other chemicals on BglG167b activity were also determined. BglG167b activity was tested in the presence of 1 or $10 \mathrm{mM}$ (final concentration) of $\mathrm{CaCl}_{2}, \mathrm{CoCl}_{2}, \mathrm{CuCl}_{2}, \mathrm{KCl}$, $\mathrm{MgCl}_{2}, \mathrm{NaCl}, \mathrm{ZnCl}_{2}$, dithiothreitol (DTT), EDTA, or SDS for $30 \mathrm{~min}$ at $25^{\circ} \mathrm{C}$. The remaining activity was determined and expressed as a percentage of the activity obtained in the absence of the compound.

Substrate preference was determined using $2.0 \mathrm{mM}$ chromogenic o-nitrophenyl $(o \mathrm{NP})$ and $p$-nitrophenyl ( $p \mathrm{NP}$ ) as surrogate substrates (all from Sigma) at $37^{\circ} \mathrm{C}$ for $10 \mathrm{~min}$, with one unit being defined as the release of $1 \mu \mathrm{mol} p$-nitrophenol or $o$-nitrophenol per min.

\subsection{Biotransformation Activity of Ginsenosides Using BglG167b}

The initial biotransformation experiments using the major ginsenosides $\mathrm{Rb}_{1}$ and $\mathrm{Re}$ as substrates revealed that the GST-fused enzyme does not affect the activities of BglG167b. Therefore, the fusion protein (GST-BglG167b) was used to determine the specificity and selectivity of the enzymes for the hydrolysis of the glucose moieties attached at the $\mathrm{C} 3$ and $\mathrm{C} 20$ positions in the seven PPD ginsenosides and two PPT ginsenosides. The purified enzyme at a concentration of $1.0 \mathrm{mg} / \mathrm{mL}$ in $50 \mathrm{mM}$ of sodium phosphate buffer ( $\mathrm{pH}$ 7.0) were reacted with an equal volume of $\mathrm{Rb}_{1}, \mathrm{Rb}_{2}, \mathrm{Rc}$, Rd, GypXVII, $\operatorname{Rg}_{3}(S), \mathrm{F}_{2}$, $\mathrm{Re}$, and $\mathrm{Rg}_{1}$ solution at a concentration of $2 \mathrm{mg} / \mathrm{mL}$ in $50 \mathrm{mM}$ of sodium phosphate buffer ( $\left.\mathrm{pH} 7.0\right)$ at $37^{\circ} \mathrm{C}$. The samples were taken at regular intervals and analyzed via TLC after pretreatment (see analytic methods). For TLC analysis, an equal volume of water-saturated $n$-butanol was added to stop the reaction, and the reactant present in the $n$-butanol fraction was determined.

\subsection{Gram-Scale GypLXXV Production Using Recombinant BglG167b}

Preparation of Recombinant BglG167b Using High Cell Density Culture

For the production of the recombinant BglG167b, the LB medium supplemented with ampicillin $(100 \mathrm{mg} / \mathrm{mL}$ ) was used to cultivate the E. coli BL21 (DE3) harboring $p G E X-B g 1 G 167 \mathrm{~b}$ in a $10 \mathrm{~L}$ tank reactor (Hanil science Co., Seoul, Korea) with a $5 \mathrm{~L}$ working volume at a $500 \mathrm{rpm}$ stirring speed. The $\mathrm{pH}$ value of the medium was adjusted to 7.0 by the addition of $(29 \%, v / v)$ of $\mathrm{NH}_{4} \mathrm{OH}$ and / or $(37 \%, v / v) \mathrm{HCl}$. The culture was incubated at $37^{\circ} \mathrm{C}$ until the culture reached an OD600 of 3.0.

Cells harboring pGST-BglG167b were induced at $18^{\circ} \mathrm{C}$ for $18 \mathrm{~h}$ and were then harvested via centrifugation at $5000 \mathrm{rpm}$ for $20 \mathrm{~min}$ at $4{ }^{\circ} \mathrm{C}$. Cell pellets were resuspended in 10 volumes $(w / v)$ of $50 \mathrm{mM}$ sodium phosphate buffer ( $\mathrm{pH}$ 7.0) and disrupted by sonication, and the supernatant was used as the crude enzyme for ginsenoside biotransformation.

GypXVII had been produced from $\mathrm{Rb}_{1}$ using recombinant BgpA (17). The scaled-up biotransformation of GypXVII into GypLXXV was performed in a $5.0 \mathrm{~L}$ glass bottle $(2.0 \mathrm{~L}$ working volume) under optimal conditions (shaking $200 \mathrm{rpm}$ for $8 \mathrm{~h}$ at $\mathrm{pH} 7.0$ and $37^{\circ} \mathrm{C}$ ). The reaction consisted of crude recombinant 1.0 L BglG167b, $10 \mathrm{~g}$ of GypXVII in $1.0 \mathrm{~L}$ of $50 \mathrm{mM}$ sodium phosphate buffer. Samples were collected at regular intervals and HPLC was used to monitor the biotransformation of GypXVII to GypLXXV, respectively.

\subsection{Purification of GypLXXV}

Following the $2.0 \mathrm{~L}$ reaction of GypXVII with BglG167b, the mixture was cooled at $4{ }^{\circ} \mathrm{C}$ and centrifuged at $5000 \mathrm{rpm}$ for $20 \mathrm{~min}$. The supernatants and precipitates were processed separately in order to purify the samples. The precipitate was also dissolved in $5.0 \mathrm{~L}$ of $70 \%$ ethanol solution twice and filtered using a filter paper (Advantec., Tokyo, Japan). The ethanol extracts were combined with the supernatant and adjusted to be a $45 \%$ ethanol solution. The column chromatography $(3170(\mathrm{~L}) \times$ 128 (D) mm; Doointech, Korea) packed with HP20 resin (Mitsubishi Chemical Corp., Tokyo, Japan) was adopted in order to remove the impurities, except the ginsenosides. The free sugar molecules and 
unwanted hydrophilic compounds from the HP-20 that were adsorbed in beads were washed with three bed volumes (BV) of water, and the adsorbed ginsenosides were finally eluted using 3 BVs of 95\% ethanol. The ethanol eluent was evaporated in vacuo. The resulting powder was dissolved in $100 \%$ methanol and analyzed via HPLC.

GypLXXV was further purified using preparative HPLC (JAL Recycling Preparative HPLC LC-9210II NEXT, Japan Analytical Industry Co., Tokyo, Japan). The preparative HPLC run was performed using a pre-packed column (JAIGEL-ODS-AP-L, $20 \mathrm{~mm}$ i.d. $\times 500 \mathrm{~mm}$ ) purchased from Japan Analytical Industry Co. (Tokyo, Japan). The mobile phase was $85 \%$ acetonitrile, and the flow rate was $7.0 \mathrm{~mL} / \mathrm{min}$. The sample solution was made by dissolving a sufficient quantity of crude GypLXXV in $85 \%$ acetonitrile to give a final concentration of $30 \mathrm{mg} / \mathrm{mL}$ and $10 \mathrm{~mL}$ was loaded for the purification. GypLXXV was returned to the column after passing through the detector two times to achieve a higher purification. The elutionfrom $70 \mathrm{~min}$ to $77 \mathrm{~min}$ was collected, evaporated and analyzed by HPLC.

\subsection{Cell Culture}

Cancer cells were maintained in Dulbecco's Modified Eagle's Medium (DMEM) with 10\% FBS, $2 \mathrm{mmol} / \mathrm{L}$ glutamine, $100 \mathrm{U} / \mathrm{mL}$ penicillin, and $100 \mathrm{mg} / \mathrm{mL}$ streptomycin at $37^{\circ} \mathrm{C}$ in a humidified $5 \%$ $\mathrm{CO}_{2}$ atmosphere. Appropriate amounts of the resulting GypLXXV in DMSO were added to the culture medium at the indicated final concentrations.

\subsection{MTT Assay}

The in vitro chemosensitivity was measured by dimethyl thiazolyl-2,5-diphenyltetrazolium bromide (MTT) assay (CellTiter $96^{\circledR}$ Non-Radioactive Cell Proliferation Assay kit, Promega, Madison, WI, USA). Briefly, Cancer cells were inoculated into 96-well plates in $100 \mu \mathrm{L}$ medium (10 ${ }^{4}$ cells) per well and allowed to attach and grow for $24 \mathrm{~h}$. To determine the anti-proliferative effect of GypLXXV, $\operatorname{Rg}_{3}(S), \mathrm{Rb}_{1}$ and GypXVII, various concentrations of ginsenosides diluted with the FBS-free medium were added into the wells. Then the cells were exposed to drugs for $48 \mathrm{~h}$ at $37^{\circ} \mathrm{C}$, after which, MTT was added to each well and cultured for an additional $4 \mathrm{~h}$. The formed formazan was dissolved in $100 \mu \mathrm{L}$ of solubilization/stop solution after aspirating the culture medium. The plates were shaken mechanically for $5 \mathrm{~min}$ and incubated for $1 \mathrm{~h}$. After shearing for each well the optical density was immediately read on a microplate reader at a wavelength of $595 \mathrm{~nm}$. Results are expressed as $\mathrm{LC}_{50}$ which was analyzed by GraphPad Prism 5 program.

\subsection{Analytic Methods}

\subsubsection{Thin Layer Chromatography (TLC) Analysis}

The thin layer chromatography (TLC) was performed using $60 \mathrm{~F}_{254}$ silica gel plates (Merck \& Co., Munchen, Germany) with $\mathrm{CHCl}_{3}-\mathrm{CH}_{3} \mathrm{OH}-\mathrm{H}_{2} \mathrm{O}(70: 30: 10$, lower phase) as the solvent. The spots on the TLC plates were identified through comparisons with standard ginsenoside after visualization was made by spraying $10 \%(v / v) \mathrm{H}_{2} \mathrm{SO}_{4}$, followed by heating at $110{ }^{\circ} \mathrm{C}$ for $5 \mathrm{~min}$.

\subsubsection{High-Performance Liquid Chromatography (HPLC) Analysis}

The HPLC analysis of the ginsenosides was performed using an HPLC system (Younglin Co. Ltd., Anyang-si, Korea). The separation was performed on a Prodigy ODS(2) $\mathrm{C}_{18}$ column $(5 \mu \mathrm{m}$, $150 \times 4.6 \mathrm{~mm}$ i.d.; Phenomenex Inc., Torrance, CA, USA) with a guard column (Eclipse XDB C $18,5 \mu \mathrm{m}$, $12.5 \times 4.6 \mathrm{~mm}$ i.d.). The mobile phases were $\mathrm{A}$ (acetonitrile) and $\mathrm{B}$ (water). The gradient elution started with 32\% solvent $\mathrm{A}$, and was changed to the following: from 0-8 min, A was increased from 32 to 65\%; from 8-12 min, A was increased from 65 to 100\%; from 12-15 min, A was constant at 100\%; from 15-15.1 min, A was decreased from 100 to 32\%; from 15.1-25 min, A was constant at 32\% The flow rate 
was $1.0 \mathrm{~mL} / \mathrm{min}$, and the detection was measured by monitoring the absorbance at $203 \mathrm{~nm}$ and with an injected volume of $25 \mu \mathrm{L}$.

\subsection{Nucleotide Sequence Accession Numbers}

The sequence for the BglG167b gene from Microbacterium sp. Gsoil 167 was deposited into GenBank/EMBL/DDBJ under accession numbers JX960414.

\section{Conclusions}

In summary, we have cloned and characterized ginsenoside-transforming $\beta$-glucosidase belonging to the glycoside hydrolases superfamily 3 from Microbacterium sp. Gsoil 167 from the ginseng-cultivating soil. This had optimum reaction conditions at $37^{\circ} \mathrm{C}$ and $\mathrm{pH} 7.0$. BglG167b could convert various ginsenosides ( $\mathrm{Rb}_{1}, \mathrm{Rb}_{2}, \mathrm{Rc}, \mathrm{Rd}, \mathrm{GypXVII}, \mathrm{Rg}_{3}(S), \mathrm{F}_{2}, \mathrm{Re}$, and $\operatorname{Rg}_{1}$ ) through the selective hydrolysis of only the glucose moieties. Among them, this enzyme efficiently hydrolyzes one inner glucose moiety at the $\mathrm{C} 3$ position of PPD type ginsenosides ( $\mathrm{F}_{2}$ and GypXVII). The recombinant BglG167b was applied to produce GypLXXV on the gram-scale and scale-up of production using $10 \mathrm{~g}$ of the GypXVII resulting in $5.7 \mathrm{~g}$ of GypLXXV with $97.8 \%$ chromatography purity and $69.6 \%$ recovery. The anti-cancer activity of this compound was primarily determined in vitro. GypLXXV showed strong cancer cell growth inhibition of cancer cells, and the activity is similar with the well-known anti-cancer ginsenoside- $\operatorname{Rg}_{3}(S)$ which showed its possibility for the application. Therefore, the properties of BglG167b could be a useful tool in the research and production of GypLXXV in the cosmetics, functional food, and pharmaceutical industries.

Supplementary Materials: Supplementary materials are available online.

Acknowledgments: This work was supported by the Intelligent Synthetic Biology Center of Global Frontier Project funded by the Ministry of Science, ICT and Future Planning (2014M3A6A8066437), Republic of Korea.

Author Contributions: The list authors contributed to this work as follows: Chang-Hao Cui, Sun-Chang Kim and Wan-Taek Im conceived and designed the experiments; Chang-Hao Cui, performed the experiments and analyzed the data; Da Jung Kim and Suk-Chae Jung contributed reagents/materials/analysis tools; Chang-Hao Cui and Wan-Taek Im wrote the paper. Sun-Chang Kim and Wan-Taek Im acquired funding for the research. All authors read and approved the final manuscript.

Conflicts of Interest: The authors declare no competing financial interest.

\section{References}

1. Shi, Y.; Sun, C.J.; Zheng, B.; Gao, B.; Sun, A.M. Simultaneous determination of ten ginsenosides in American ginseng functional foods and ginseng raw plant materials by liquid chromatography tandem mass spectrometry. Food. Anal. Methods 2013, 6, 112-122. [CrossRef]

2. Wang, C.Z.; Yuan, C.S. Potential role of ginseng in the treatment of colorectal cancer. Am. J. Chin. Med. 2008, 36, 1019-1028. [CrossRef] [PubMed]

3. Xu, X.H.; Li, T.; Fong, C.M.V.; Chen, X.P.; Chen, X.J.; Wang, Y.T.; Huang, M.Q.; Lu, J.J. Saponins from Chinese Medicines as Anticancer Agents. Molecules 2016, 21, 1326. [CrossRef] [PubMed]

4. Cao, B.; Liu, X.; Li, J.; Liu, S.; Qi, Y.; Xiong, Z.; Zhang, A.; Wiese, T.; Fu, X.; Gu, J.; et al. 20(S)-Protopanaxadiolaglycone downregulation of the full-length and splice variants of androgen receptor. Int. J. Cancer 2013, 132, 1277-1287. [CrossRef] [PubMed]

5. Kim, M.S.; Lee, K.T.; Iseli, T.J.; Hoy, A.J.; George, J.; Grewal, T.; Roufogalis, B.D. Compound K modulates fatty acid-induced lipid droplet formation and expression of proteins involved in lipid metabolism in hepatocytes. Liver Int. 2013, 33, 1583-1593. [CrossRef] [PubMed]

6. Lian, L.H.; Jin, Q.; Song, S.Z.; Wu, Y.L.; Bai, T.; Jiang, S.; Li, Q.; Yang, N.; Nan, J.X. Ginsenoside Rh downregulates LPS-induced NF-kappa B activation through inhibition of TAK1 phosphorylation in RAW 264.7 murine macrophage. Evid. Based Complement. Altern. Med. 2013, 2013, 646728. [CrossRef] [PubMed]

7. Qi, L.W.; Wang, C.Z.; Yuan, C.S. American ginseng: Potential structure-function relationship in cancer chemoprevention. Biochem. Pharmacol. 2010, 80, 947-954. [CrossRef] [PubMed] 
8. Song, M.Y.; Kim, B.S.; Kim, H. Influence of Panax ginseng on obesity and gut microbiota in obese middle-aged Korean women. J. Ginseng Res. 2014, 38, 106-115. [CrossRef] [PubMed]

9. Wang, H.P.; Zhang, Y.B.; Yang, X.W.; Yang, X.B.; Xu, W.; Xu, F.; Cai, S.Q.; Wang, Y.P.; Xu, Y.H.; Zhang, L.X. High-Performance Liquid Chromatography with Diode Array Detector and Electrospray Ionization Ion Trap Time-of-Flight Tandem Mass Spectrometry to Evaluate Ginseng Roots and Rhizomes from Different Regions. Molecules 2016, 21, 603. [CrossRef] [PubMed]

10. Kim, Y.J.; Jeon, J.N.; Jang, M.G.; Oh, J.Y.; Kwon, W.S.; Jung, S.K.; Yang, D.C. Ginsenoside profiles and related gene expression during foliation in Panax ginseng Meyer. J. Ginseng Res. 2014, 38, 66-72. [CrossRef] [PubMed]

11. Zhang, C.Y.; Dong, L.; Wang, J.; Chen, S.L. Simultaneous determination of ten ginsenosides in panacis quinquefolii radix by ultra performance liquid chromatography and quality evaluation based on chemometric methods. Pharmazie 2011, 66, 553-559. [PubMed]

12. Kang, M.S.; Baek, S.H.; Chun, Y.S.; Moore, A.Z.; Landman, N.; Berman, D.; Yang, H.O.; Morishima-Kawashima, M.; Osawa, S.; Funamoto, S.; et al. Modulation of lipid kinase PI4KIIalpha activity and lipid raft association of presenilin 1 underlies gamma-secretase inhibition by ginsenoside (20S)- $\mathrm{Rg}_{3}$. J. Biol. Chem. 2013, 288, 20868-20882. [CrossRef] [PubMed]

13. Zhang, Z.; Du, G.J.; Wang, C.Z.; Wen, X.D.; Calway, T.; Li, Z.; He, T.C.; Du, W.; Bissonnette, M.; Musch, M.W.; et al. Compound K, a ginsenoside metabolite, inhibits colon cancer growth via multiple pathways including p53-p21 interactions. Int. J. Mol. Sci. 2013, 14, 2980-2995. [CrossRef] [PubMed]

14. Cui, J.F.; Eneroth, P.; Bruhn, J. Gynostemma pentaphyllum: Identification of major sapogenins and differentiation from Panax species. Eur. J. Pharm. Sci. 1999, 8, 187-191. [CrossRef]

15. Qi, L.W.; Wang, C.Z.; Yuan, C.S. Isolation and analysis of ginseng: Advances and challenges. Nat. Prod. Rep. 2011, 28, 467-495. [CrossRef] [PubMed]

16. Open Reading Frame Finder. Available online: https://www.ncbi.nlm.nih.gov/orffinder/ (accessed on 17 May 2017).

17. Compute pI/Mw tool, ExPASy Server. Available online: http://web.expasy.org/compute_pi/ (accessed on 17 May 2017).

18. Castle, L.A.; Smith, K.D.; Morris, R.O. Cloning and sequencing of an Agrobacterium tumefaciens $\beta$-glucosidase gene involved in modifying a vir-inducing plant signal molecule. J. Bacteriol. 1992, 174, 1478-1486. [CrossRef] [PubMed]

19. Bao, L.; Huang, Q.; Chang, L.; Sun, Q.W.; Zhou, J.G.; Lu, H. Cloning and characterization of two $\beta$-glucosidase/xylosidase enzymes from Yak rumen metagenome. Appl. Biochem. Biotechnol. 2012, 166, $72-86$. [CrossRef] [PubMed]

20. Wong, W.K.; Ali, A.; Chan, W.K.; Ho, V.; Lee, N.T. The cloning, expression and characterization of a cellobiase gene encoding a secretory enzyme from Cellulomonas biazotea. Gene 1998, 207, 79-86. [CrossRef]

21. Feng, Y.; Duan, C.J.; Pang, H.; Mo, X.C.; Wu, C.F.; Yu, Y.; Hu, Y.L.; Wei, J.; Tang, J.L.; Feng, J.X. Cloning and identification of novel cellulase genes from uncultured microorganisms in rabbit cecum and characterization of the expressed cellulases. Appl. Microbiol. Biotechnol. 2007, 75, 319-328. [CrossRef] [PubMed]

22. An, D.S.; Cui, C.H.; Lee, H.G.; Wang, L.; Kim, S.C.; Lee, S.T.; Jin, F.X.; Yu, H.S.; Chin, Y.W.; Lee, H.K.; et al. Identification and characterization of a novel Terrabacter ginsenosidimutans sp. nov. $\beta$-glucosidase that transforms ginsenoside $\mathrm{Rb}_{1}$ into the rare gypenosides XVII and LXXV. Appl. Environ. Microbiol. 2010, 76, 5827-5836. [CrossRef] [PubMed]

23. Cui, C.H.; Kim, S.C.; Im, W.T. Characterization of the ginsenoside-transforming recombinant $\beta$-glucosidase from Actinosynnema mirum and bioconversion of major ginsenosides into minor ginsenosides. Appl. Microbiol. Biotechnol. 2013, 97, 649-659. [CrossRef] [PubMed]

24. Jung, I.H.; Lee, J.H.; Hyun, Y.J.; Kim, D.H. Metabolism of ginsenoside Rb $b_{1}$ by human intestinal microflora and cloning of its metabolizing $\beta$-D-glucosidase from Bifidobacterium longum H-1. Biol. Pharm. Bull. 2012, 35, 573-581. [CrossRef] [PubMed]

25. Kim, J.K.; Cui, C.H.; Yoon, M.H.; Kim, S.C.; Im, W.T. Bioconversion of major ginsenosides $\operatorname{Rg}_{1}$ to minor ginsenoside $\mathrm{F}_{1}$ using novel recombinant ginsenoside hydrolyzing glycosidase cloned from Sanguibacter keddieii and enzyme characterization. J. Biotechnol. 2012, 161, 294-301. [CrossRef] [PubMed]

26. Quan, L.H.; Min, J.W.; Jin, Y.; Wang, C.; Kim, Y.J.; Yang, D.C. Enzymatic Biotransformation of Ginsenoside $\mathrm{Rb}_{1}$ to Compound $\mathrm{K}$ by Recombinant $\beta$-Glucosidase from Microbacterium esteraromaticum. J. Agric. Food Chem. 2012, 60, 3776-3781. [CrossRef] [PubMed] 
27. Quan, L.H.; Min, J.W.; Sathiyamoorthy, S.; Yang, D.U.; Kim, Y.J.; Yang, D.C. Biotransformation of ginsenosides Re and $\operatorname{Rg}_{1}$ into ginsenosides $\operatorname{Rg}_{2}$ and $\mathrm{Rh}_{1}$ by recombinant $\beta$-glucosidase. Biotechnol. Lett. 2012, 34, $913-917$. [CrossRef] [PubMed]

28. Quan, L.H.; Min, J.W.; Yang, D.U.; Kim, Y.J.; Yang, D.C. Enzymatic biotransformation of ginsenoside Rb $b_{1}$ to 20(S)- $\mathrm{Rg}_{3}$ by recombinant $\beta$-glucosidase from Microbacterium esteraromaticum. Appl. Microbiol. Biotechnol. 2012, 94, 377-384. [CrossRef] [PubMed]

29. Ruan, C.C.; Zhang, H.; Zhang, L.X.; Liu, Z.; Sun, G.Z.; Lei, J.; Qin, Y.X.; Zheng, Y.N.; Li, X.; Pan, H.Y. Biotransformation of ginsenoside $R_{\mathrm{f}}$ to $\mathrm{Rh}_{1}$ by recombinant $\beta$-glucosidase. Molecules 2009, 14, 2043-2048. [CrossRef] [PubMed]

30. Cui, C.H.; Liu, Q.M.; Kim, J.K.; Sung, B.H.; Kim, S.G.; Kim, S.C.; Im, W.T. Identification and Characterization of Mucilaginibacter sp. QM49 $\beta$-Glucosidase and its use in Producing the Pharmaceutically Active Minor Ginsenosides, $\operatorname{Rh}_{1}(S)$ and $\operatorname{Rg}_{2}(S)$. Appl. Environ. Microbiol. 2013, 79, 5788-5798. [CrossRef] [PubMed]

31. Kim, J.K.; Cui, C.H.; Liu, Q.; Yoon, M.H.; Kim, S.C.; Im, W.T. Mass production of the ginsenoside $\operatorname{Rg}_{3}(S)$ through the combinative use of two glycoside hydrolases. Food Chem. 2013, 141, 1369-1377. [CrossRef] [PubMed]

32. Hou, J.G.; Xue, J.J.; Sun, M.Q.; Wang, C.Y.; Liu, L.; Zhang, D.L.; Lee, M.R.; Gu, L.J.; Wang, C.L.; Wang, Y.B.; et al. Highly selective microbial transformation of major ginsenoside $\mathrm{Rb}_{1}$ to gypenoside $\mathrm{LXXV}$ by Esteya vermicola CNU120806. J. Appl. Microbiol. 2012, 113, 807-814. [CrossRef] [PubMed]

33. Cui, C.H.; Kim, J.K.; Kim, S.C.; Im, W.T. Characterization of a ginsenoside-transforming $\beta$-glucosidase from Paenibacillus mucilaginosus and its application for enhanced production of minor ginsenoside $\mathrm{F}_{2}$. PLoS ONE 2014, 9, e85727. [CrossRef] [PubMed]

34. Du, J.; Cui, C.H.; Park, S.C.; Kim, J.K.; Yu, H.S.; Jin, F.X.; Sun, C.; Kim, S.C.; Im, W.T. Identification and characterization of a ginsenoside-transforming $\beta$-glucosidase from Pseudonocardia sp. Gsoil 1536 and its application for enhanced production of minor ginsenoside $\operatorname{Rg}_{2}(S)$. PLoS ONE 2014, 9, e96914. [CrossRef] [PubMed]

35. Cheng, L.Q.; Na, J.R.; Bang, M.H.; Kim, M.K.; Yang, D.C. Conversion of major ginsenoside Rb $b_{1}$ to 20(S)-ginsenoside $\operatorname{Rg}_{3}$ by Microbacterium sp. GS514. Phytochemistry 2008, 69, 218-224. [CrossRef] [PubMed]

36. Kim, W.Y.; Kim, J.M.; Han, S.B.; Lee, S.K.; Kim, N.D.; Park, M.K.; Kim, C.K.; Park, J.H. Steaming of ginseng at high temperature enhances biological activity. J. Nat. Prod. 2000, 63, 1702-1704. [CrossRef] [PubMed]

37. Liu, L.; Zhu, X.M.; Wang, Q.J.; Zhang, D.L.; Fang, Z.M.; Wang, C.Y.; Wang, Z.; Sun, B.S.; Wu, H.; Sung, C.K. Enzymatic preparation of 20(S,R)-protopanaxadiol by transformation of $20(S, R)-\mathrm{Rg}_{3}$ from black ginseng. Phytochemistry 2010, 71, 1514-1520. [CrossRef] [PubMed]

38. Hong, H.; Cui, C.H.; Kim, J.K.; Jin, F.X.; Kim, S.C.; Im, W.T. Enzymatic Biotransformation of Ginsenoside $\mathrm{Rb}_{1}$ and Gypenoside XVII into Ginsenosides $\mathrm{Rd}$ and $\mathrm{F}_{2}$ by Recombinant $\beta$-glucosidase from Flavobacterium johnsoniae. J. Ginseng Res. 2012, 36, 418-424. [CrossRef] [PubMed]

39. Zhong, F.L.; Dong, W.W.; Wu, S.Q.; Jiang, J.; Yang, D.C.; Li, D.H.; Quan, L.H. Biotransformation of gypenoside XVII to compound $\mathrm{K}$ by a recombinant $\beta$-glucosidase. Biotechnol. Lett. 2016, 38, 1187-1193. [CrossRef] [PubMed]

40. Wong, A.S.T.; Che, C.M.; Leung, K.W. Recent advances in ginseng as cancer therapeutics: A functional and mechanistic overview. Nat. Prod. Rep. 2015, 32, 256-272. [CrossRef] [PubMed]

41. Liu, T.G.; Huang, Y.; Cui, D.D.; Huang, X.B.; Mao, S.H.; Ji, L.L.; Song, H.B.; Yi, C. Inhibitory effect of ginsenoside $\mathrm{Rg}_{3}$ combined with gemcitabine on angiogenesis and growth of lung cancer in mice. BMC Cancer 2009, 9, 250. [CrossRef] [PubMed]

42. Mai, T.T.; Moon, J.; Song, Y.; Viet, P.Q.; Phuc, P.V.; Lee, J.M.; Yi, T.H.; Cho, M.; Cho, S.K. Ginsenoside F $_{2}$ induces apoptosis accompanied by protective autophagy in breast cancer stem cells. Cancer Lett. 2012, 321, 144-153. [CrossRef] [PubMed]

43. Cui, C.H.; Im, W.T.; Kim, S.C. Composition for Preventing or Treating Cervical Cancer including Gypenoside LXXV. Patent WO2017026641 A1, 16 February 2017.

44. Carbohydrate-Active enZymes Database. Available online: http:/ / www.cazy.org (accessed on 17 May 2017).

45. Thompson, J.D.; Gibson, T.J.; Plewniak, F.; Jeanmougin, F.; Higgins, D.G. The CLUSTAL_X windows interface: Flexible strategies for multiple sequence alignment aided by quality analysis tools. Nucleic Acids Res. 1997, 25, 4876-4882. [CrossRef] [PubMed] 
46. Hall, T.A. BioEdit: A user-friendly biological sequence alignment editor and analysis program for Windows 95/98/NT. Nucleic Acids Symp. Ser. 1999, 41, 95-98.

47. Kimura, M. The Neutral Theory of Molecular Evolution; Cambridge University Press: Cambridge, UK, 1983.

48. Tamura, K.; Peterson, D.; Peterson, N.; Stecher, G.; Nei, M.; Kumar, S. MEGA5: Molecular evolutionary genetics analysis using maximum likelihood, evolutionary distance, and maximum parsimony methods. Mol. Biol. Evol. 2011, 28, 2731-2739. [CrossRef] [PubMed]

Sample Availability: Samples of the compounds Gypenoside XVII and Gypenoside LXXV are available from the authors.

(C) 2017 by the authors. Licensee MDPI, Basel, Switzerland. This article is an open access article distributed under the terms and conditions of the Creative Commons Attribution (CC BY) license (http://creativecommons.org/licenses/by/4.0/). 